Check for updates

Department of Demography, University of California, Berkeley, CA, USA

2 French Institute for Demographic Studies (INED), Paris, France

magali@berkeley.edu Cite this as: BMJ 2021;373:n1530 http://dx.doi.org/10.1136/bmj.n1530 Published: 24 June 2021

\title{
Covid-19 and the growing disadvantage in US life expectancy
}

\section{The pandemic has magnified pre-existing vulnerabilities in US society}

\section{Magali Barbieri researcher ,2}

With 600 ooo deaths from covid-19 as of mid-June 2021, more people have died of the disease in the United States than in any other country. As shown in the linked paper by Woolf and colleagues (doi:10.1136/bmj.n1343), ${ }^{1}$ not only have Americans been dying from covid-19 at faster rates than their peers in other comparable countries, but they have also been dying at younger ages, resulting in a disproportionately large number of years of life lost to the virus than elsewhere.

While the populations of 16 established market economies lost an average of 0.22 years of life in 2020, the loss was 1.87 years in the United States. Woolf and colleagues also show that the higher death toll of covid-19 is not solely attributable to the large disparities in race and ethnicity within the US, although such disparities are undeniable. It is absolutely true that mortality rates from covid-19 have been much higher among African-Americans than among White Americans, reversing the progress in reducing the gap in life expectancy between the two groups that had been achieved over the previous 20 years. Hispanic people, who had enjoyed higher life expectancy at birth than non-Hispanic people (a well documented paradox), ${ }^{2}$ have also had an unprecedented increase in mortality, eliminating their previous advantage. Woolf and colleagues' results confirm findings from studies based on preliminary results that showed reductions in life expectancy three to four times larger for Black and Hispanic people than for White people. ${ }^{3}$ However, even White Americans lost more years of life than their counterparts in peer countries (1.36 years $v 0.22$ years).

Even before the pandemic, the US international ranking on life expectancy was poor. According to the most recent data published by the World Health Organization, in 2019 the US ranked 41st for men and 42nd for women in life expectancy at birth. ${ }^{4}$ The number of years that Americans could expect to live was similar to that in Peru, Colombia, Chile, Croatia, and Thailand, and just ahead of China, Cuba, and Turkey (for women). Life expectancy in the US was shorter than in other high income democracies, such as those in western, northern, and southern Europe, Canada, and Australia, and especially in Japan and the Republic of Korea, the top ranking countries. This poor ranking was not related to a lack of funding for healthcare. In 2017, the US was by far the largest spender, with $17 \%$ of its gross domestic product (GDP) dedicated to healthcare. ${ }^{5}$ The next highest spender was Switzerland at $12 \%$, where people could expect to live 4.7 years longer than in the US. In Italy, which spent only $9 \%$ of its GDP on healthcare, the expectation of life at birth was 3.8 years higher than for Americans in 2017.
The US disadvantage in mortality compared with other high income democracies in 2020 is neither new nor sudden. It is part of a long term trend that had further deteriorated in the years leading to the pandemic. In 1950, the country ranked comfortably above the average of its peers for both men and women. After multiple decades of rapid growth resulting from the control of infectious diseases and the introduction of new treatments and mass vaccination programmes, progress slowed or stalled altogether from the mid-1950s to about 1970 in all advanced countries, including the US. ${ }^{6}$ The cardiovascular revolution allowed progress to resume starting around 1970 but more slowly in the US than in other high income market economies. ${ }^{7}$

The gap in life expectancy at birth in the US further increased in the 21st century, progressively at first, and more rapidly after 2010, when the death rates first stagnated and then started increasing for Americans while they continued to decline in other wealthy countries. This long term trend of falling behind other peer countries has been attributed to a range of factors. ${ }^{9}$ However, the accelerated deterioration since 2010 is largely a result of the drug overdose epidemic, affecting mostly working age adults of both sexes, and to a considerable slowing down of declines in cardiovascular mortality, both in absolute terms and relative to other countries. ${ }^{1011}$

The covid-19 pandemic has thus operated as a magnifier of already existing vulnerabilities within the US population. Understanding the reasons for the disproportionate toll of the disease on the US population and developing appropriate interventions and policies provides an opportunity to correct the structural factors that have historically hampered US progress in life expectancy and that have driven large social and racial and ethnic inequities in the risks of death.

Competing interests: I have read and understood the BMJ Group policy on declaration of interests and declare the following interests: The author has been provided funding by the Society of Actuaries and by the UK Institute and Faculty of Actuaries. In addition, a project led by the author, the Human Mortality Database, has received gifts from the Canadian Institute of Actuaries and from commercial insurance or re-insurance companies (SCOR, Hannover-Re, Reinsurance Of America, Munich-Re, and Milliman-France, Club Vita). The author is an unpaid volunteer member of the Society of Actuary Mortality and Longevity Steering Committee.

Provenance and peer review: Commissioned; not externally peer reviewed.

Woolf SH, Masters RK, Aron LY. Effect of the covid-19 pandemic in 2020 on life expectancy across populations in the USA and other high income countries: simulations of provisional mortality data. BMJ2021;373:n1343. Markides KS, Eschbach K. Aging, migration, and mortality: current status of research on the Hispanic paradox. J Gerontol B Psychol Sci Soc Sci 2005;60:S68-75. 
3 Andrasfay T, Goldman N. Reductions in 2020 US life expectancy due to COVID-19 and the disproportionate impact on the Black and Latino populations. Proc Natl Acad Sci U S A 2021;118:e2014746118. doi: 10.1073/pnas.2014746118 pmid: 33446511

4 World Health Organization. Mortality database. https:/www.who.int/data/gho/data/indicators/indicator-details/GHO/life-expectancy-at-birth-(years).

5 Organisation for Economic Co-operation and Development. Health at a glance 2019: OECD indicators. OECD Publishing, 2019

6 Crimmins EM, Preston SH, Cohen B, eds. International Differences in Mortality at Older Ages: Dimensions and Sources. National Research Council. Committee on Population. National Academy of Sciences, 2011:1-13.

7 Ouellette N, Barbieri M, Wilmoth JR. Period-Based Mortality Change: Turning Points in Trends since 1950. Popul Dev Rev 2014;40:77-106 doi: 10.1111/j.1728-4457.2014.00651.x pmid: 25018570

8 Mesle F, Vallin J. Diverging trends in female old-age mortality: the United States and the Netherlands versus France and Japan. Popul Dev Rev 2006;32:123-45doi: 10.1111/j.1728-4457.2006.00108.x

9 National Research Council, Committee on Population. US health in international perspective: Shorter lives, poorer health. National Academies Press, 2013.

10 Case A, Deaton A. Deaths of Despair and the Future of Capitalism. Princeton University Press, 2020.

11 National Academies of Sciences, Engineering, and Medicine 2021. High and Rising Mortality Rates Among Working-Age Adults. National Academies Press, 2021, doi: 10.17226/25976.

This article is made freely available for use in accordance with BMJ's website terms and conditions for the duration of the covid-19 pandemic or until otherwise determined by BMJ. You may use, download and print the article for any lawful, non-commercial purpose (including text and data mining) provided that all copyright notices and trade marks are retained. 